\title{
Profile of Crude Protein Tyrosine Kinase on Plasma Membrane of Merino Sheep Spermatozoa Using the Method of SDS-Page (Sodium Dodecyl Sulphate-Polyacrilamide Gel Electrophoresis)
}

\section{Vilda Carlenia Wardani1, Sri Pantja Madyawati², and Poedji Hastutiek ${ }^{3}$}

${ }^{1}$ Student of Faculty of Veterinary Medicine, Universitas Airlangga

${ }^{2}$ Departement of Veterinary Reproduction, Faculty of Veterinary Medicine - Universitas Airlangga

${ }^{3}$ Departement of Veterinary Parasitology, Faculty of Veterinary Medicine- Universitas Airlangga Kampus C UNAIR, Jalan Mulyorejo,Surabaya-60115

\section{Abstract}

Corresponding Author: Sri Pantja Madyawati sripantja_madyawati@ yahoo.com

Received: 03 October 2017 Accepted: 10 October 2017 Published: 29 November 2017

Publishing services provided by Knowledge E

(c) Vilda Carlenia Wardani et al. This article is distributed under the terms of the Creative Commons Attribution License, which permits unrestricted use and redistribution provided that the original author and source are credited.

Selection and Peer-review under the responsibility of the VMIC Conference Committee.

\section{G OPEN ACCESS}

The research aims to find out profile of crude protein tyrosine kinase on plasma membrane of Merino sheep spermatozoa. The research used fresh semen sample collected using artificial vagina technique, next it was centrifuged to separate spermatozoa from seminal plasma. Then, spermatozoa (pellet) was isolated. After obtaining spermatozoa isolate, analysis on protein tyrosine kinase using SDS-PAGE method was conducted. The method to analyze protein using SDS-PAGE to separate protein based on molecular weight. Analysis on molecular weight was conducted by comparing result of isolate tapes with protein marker tapes. Running on SDS-PAGE gel isolate protein plasma membrane of Merino sheep spermatozoa in the research resulted in 13 protein tapes with average molecular weights of $115.44 \mathrm{kDa}$; 95.78 kDa; 78.22 kDa; 69.02 kDa; 62.33 kDa; 53.72 kDa; 40.56 kDa; 30.74 kDa; 21.16 kDa; $13.67 \mathrm{kDa} ; 10.85 \mathrm{kDa} ; 9.49$ and $8.07 \mathrm{kDa}$ kDa. From this result, the second tape with the molecular weight of $95.78 \mathrm{kDa}$ was believed to be protein tyrosine kinase tape however it needs to be confirmed further using Western Blot method.

Keywords: tyrosine kinase, membrane of Merino sheep spermatozoa, SDS-PAGE.

\section{Introduction}

Quality of frozen semen is one of the factors which determines success of artificial insemination program on sheep. Process of making frozen semen consists of process of cooling, freezing and thawing. Process of freezing and thawing can induce damage on plasma membrane of spermatozoa as during freezing process temperature change 
and osmotic pressure take place drastically, therefore metabolic change takes place fast. Damage on plasma membrane of spermatozoa physically and chemically is able to induce life of sperm and motility [1].

Sheep semen is prone to experience damage of plasma membrane. Motility rate of post thawing sheep is $34 \%$. The rate is lower than motility rate of post thawing Limousin cow that is between $43.3 \%$ and $47.5 \%$ [2]. Damage on plasma membrane of spermatozoa disturbs spermatozoa metabolism and decrease motility of spermatozoa which will lead to dead spermatozoa so that it is necessary to have an effort to improve quality of spermatozoa.

Administration of crude protein on spermatozoa resulted from swim up is able to improve quality of spermatozoa [2]. One of the proteins which is able to improve quality ofspermatozoa is tyrosine kinase which functions to stabilize covalent bonds which compose membrane protein so that it can prevent covalent bonds of spermatozoa membranes from being broken when added to diluting medium of frozen semen [3].

The result of Madyawati's research [4] tyrosine kinase resulted from Holstein Friesien cow isolate was on the head of spermatozoa with molecular weight of 95 kDa supplemented to diluting medium of frozen semen with a dosage of $200 \mu \mathrm{g} / \mathrm{ml}$ at temperature of $35^{\circ} \mathrm{C}, \mathrm{pH} 7,0$ and incubation time of 30 minutes is able to increase percentage of live spermatozoa, spermatozoa motility, and integrity of spermatozoa membrane pre and post freezing.

\section{Material and Method}

\subsection{Collection of Merino sheep semen}

Collection of Merino sheep semen was conducted by using artificial vagina for sheep. Next semen was examined macroscopically (volume, color, smell, consisency and pH) and microscopically (concentration, motility, mass movement and percentage of live spermatozoa)

\subsection{Separation of spermatozoa from seminal plasma of Merino sheep}

Semen of Merino sheep which was examined macroscopically and microscopically was then centrifuged with speed of $4000 \mathrm{rpm}$ for 40 minutes to separate spermatozoa from seminal plasma. Next only sediment was left. the sediment was pellet (spermatozoa), whereas the supernatan was seminal plasma. 


\subsection{Isolate Protein}

Pellet (spermatozoa) which was seperated from seminal plasma was supplemented with medium BO-cafein $1 \mathrm{ml}$, next centrifuged with speed of $3000 \mathrm{rpm}$ for 10 minutes. Supernatan was discarded, the sediment was supplemented with PBST (Phosoril Buffer Saline Tris) 5 times of volume and supplemented with PMSF (Phenyl Methene Sulfonyl Fluoride) as much as 5 times of volume.After that, Vortex was done for 10 minutes and sonication was done for 20 minutes. Centrifugation with the speed of 6000 rpm was done for 10 minutes. the sediment was discarded, the supernatan was supplemented with cold etanol with the ratio of $1: 1$. Then, kept in refrigerator for an hour until white spots were formed. Etanol was discarded and dried using tissue until smell of etanol was gone. After that it was supplemeted with Tris- $\mathrm{HCl}$. Final result was isolate crude protein of spermatozoa [5].

\subsection{Characterization and Identification of tyrosine kinase using SDS-PAGE (Sodium Dodecyl Sulphate-Polyacrylamide Gel Electrophoresis)}

Separating gel was put into electrophesis through wall until below upper limit and was supplemented with aquades until upper limit to make separating gel equal. Aquades was absorbed with tissue and supplemented with stacking gel through the wall until it was full. Next, comb was put into it and waited until gel was formed. Gel print was put into chamber. Then, it was soaked in running buffer. After that, it was put in the print of protein marker which would be run.

Sample of the research was isolate protein of Merino sheep spermatozoa as much as $35 \mu \mathrm{l}$ which was put into hole of print with tip of $200 \mu \mathrm{l}$. Next, chamber was connected to Biorad equipment which was powered at $130 \mathrm{~V}, 30 \mathrm{~mA}$ for 1.5 hours. When gel reaction reached the bottom, Biorad was off and plate was opened and separated. Then, it resulted in gel formed sheets which were colored with coomasie blue and shaken for 30 minutes, then they were taken out and supplemented with destaining liquid and shaken again forzo minutes. When the liquid turned blue, the liquid had to be changed with new destaining liquidand it had to be done repeatedly until the liquid turned white and it resulted in several protein tapes. Molecular weight can be seen on gel print of SDS-PAGE [6]. 
TABle 1: Result on macroscopic and microscopic examination of Merino sheep semen.

\begin{tabular}{|c|c|}
\hline Parameter & Averages \\
\hline Volum $(\mathrm{ml})$ & 1,375 \\
\hline Colour & white \\
\hline Smell & specific \\
\hline $\mathrm{pH}$ & 6,5 \\
\hline consistention & mucous \\
\hline Consentration (million/ml) & 1674 \\
\hline Mass Movement & +++ \\
\hline Individual movement & Progresif $(81,25 \%)$ \\
\hline Speed & 3 \\
\hline
\end{tabular}

\section{Result and Discussion}

Collection of Merino sheep semen was conducted twice a week within 2 week period. Every time semen was collected, macroscopic and microscopic examination was conducted. Result on macrscopic and microscopic examination of Merino sheep semen can be seen in the table 1 .

The result of macroscopic and microscopic examination in the research showed that Merino sheep semen used in the research has good quality and met the requirement to be used in isolate protein process. In line with the statement of Hardijanto [7] which stated that semen colected using artificial vagina had volume of $0.5-2.5 \mathrm{ml}$ with concentration of 15-3 million/ $\mathrm{mm}^{3}$, with mass movement between $++/+++$. Also in line with the statement of Hafez [8] stated that individual movement of good spermatozoa was around $60-80 \%$. Colors of Merino sheep semen were cream, milk white or yellow and had pH of between 6.5-7.0. Quality of Merino sheep fresh semen was influenced by several factors such as individual factor, age, weight, feed and frequency of collection [9]. According to Kartasudjana [10] normal semen usually had typical smell of the animal. When the semen smelt bad, it was assumed that there was infection on male reproductive organ.

Identification on molecular weight of Merino sheep spermatozoa protein tapes was done using the method of SDS-PAGE with concentration $12 \%$ in electrophoresis of gel protein mini set (BioRad). Protein marker used GangNam STAIN and coloring with Comassie Blue. Profile of crude protein in spermatozoa of Merino sheep can be seen in Figure 1.

Calculation of each protein tape of Merino sheep spermatozoa was conducted using regression line equation of standard curve of protein marker that is $y=-1.3607 \mathrm{x}+$ 2.1807. Result on SDS-PAGE running gel of isolate protein in Merino sheep spermatozoa in the research resulted in 13 protein tapes with average molecular weights of 115.44 kDa; 95.78 kDa; 78.22 kDa; 69.02 kDa; 62.33 kDa; 53.72 kDa; 40.56 kDa; 30.74 kDa; 21.16 kDa; $13.67 \mathrm{kDa} ; 10.85 \mathrm{kDa}$ 9.49 kDa and 8.07 kDa. 


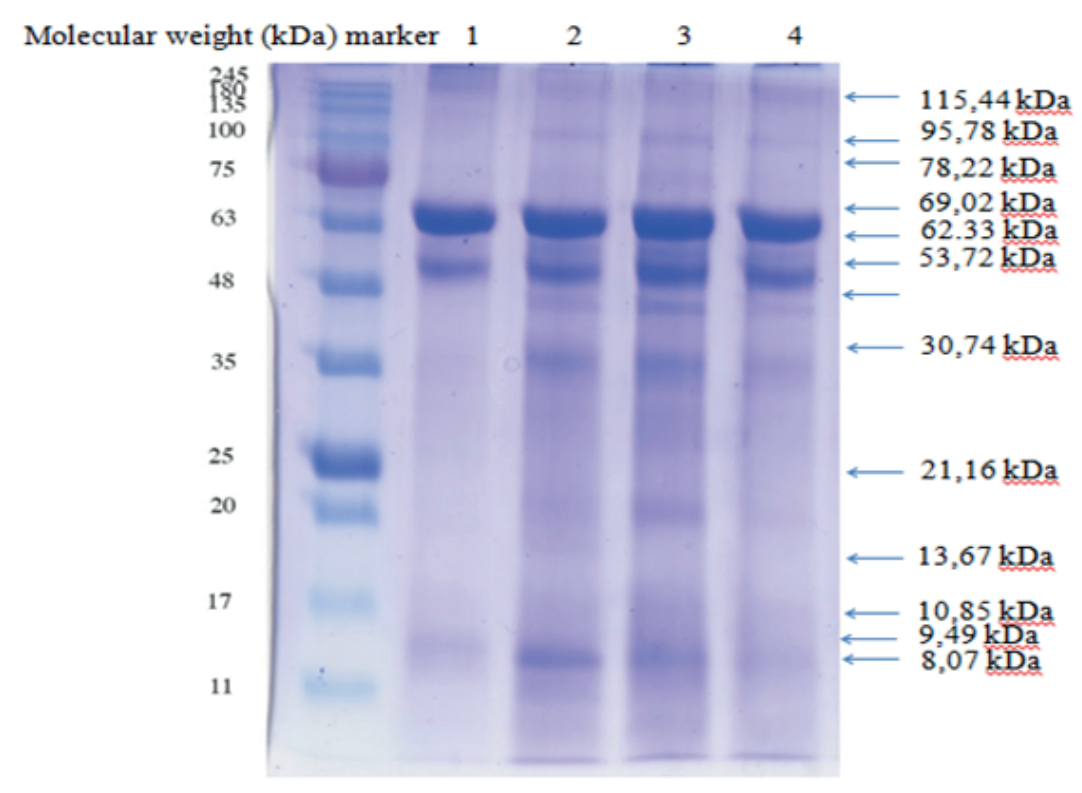

Figure 1: Profil Crude Protein Tirosin Kinase.

Several proteins in spermatozoa membrane of rat that had molecular weights of 95 , 63, 51 dan 14-18 kDa were able to bond zona pellucida proteins of ovum. However, the most potential one on autophosphorylation activity was protein with molecular weight of $95 \mathrm{kDa}$ which was classified as protein tyrosine kinase.Next, According to the research of Madyawati [4] tyrosine kinase resulted from isolate of Holstein Friesien cow was on the head of spermatozoa with molecular weight of $95 \mathrm{kDa}$. In line with result of SDS-PAGE running in the research that the second tape had a molecular weight of $95.78 \mathrm{kDa}$ yet it looked thin as Merino sheep spermatozoa might contain little protein tyrosine kinase. In line with the statement of Garner dan Hafez [8] that content of plasma protein of Merino sheep semen was $500 \mathrm{mg} / 100 \mathrm{ml}$. Next, according to research of Amin [4] content of protein plasma of cow semen was $694.6 \mathrm{mg} / 100 \mathrm{ml}$. It showed that content of plasma protein of sheep semen was lower than that of cow semen. Every animal species had different plasma membrane composition. According to Sunarto [12] that thickness of protein tapes basically was divided into two, thick and thin tapes. Thick tapes showed high protein content or high concentration yet thin tapes showed low protein content Thick protein and clearer color compared to other proteins and always existed was called major protein [13].

Other factors which caused tapes look thin were too high protein concentration, too much sample volume injected into combs, incorrect gel concentration (if protein size was unknown, gel 4\%-20\% was used), gel used was made long time ago so fresh or newly made gel was supposed to be used, too fast running process due to aqueous 
buffer, too fast running process due to too high electrical voltage, unfinished running process until last tape [11].

Sutikno [14] explained that factors which influenced tape resolution resulted from SDS-PAGE running were polyacrylamide gel concentration (concentration of monomer was proportional to last gel porosity, cross linker percentage on monomer had influence on last gel porosity, chemical substance for cross linker was able to influence porosity and next handler on last gel, monomer purity was often contaminated by acrylic acid caused by electroendosmosis at last gel) and buffer $(\mathrm{pH}$, use of continued or discontinued buffer system, buffer composition, inclusion of dissociation agents : Urea, non ionic detergent, Sodium Dodecyl Sulphate (SDS).

Technical things were able to influence result of research, in the research combs were not in line with markers so it resulted protein tapes were not linear with markers. It needed further conformation to find out that the protein was tyrosine kinase using Western Blot method.

\section{Conclusion}

Based on the research done, it can be concluded that profile of crude protein tyrosine kinase on plasma membrane of Merino sheep using method of SDS-PAGE resulted in 13 protein tapes with average molecular weight of $115.44 \mathrm{kDa} ; 95.78 \mathrm{kDa} ; 8.22 \mathrm{kDa}$; 69.02 kDa; 62.33 kDa; 53.72 kDa; 40.56 kDa; 30.74 kDa; 21.16 kDa; 13.67 kDa; 10.85 kDa; $9.49 \mathrm{kDa}$ and $8.07 \mathrm{kDa}$. The second tape showed that it had molecular weight of 95.78 kDa which was believed to be protein tyrosine kinase.

\section{ACKNOWLEDGEMENT}

The writers would like to thank Faculty of Veterinary Medicine Airlangga University for funding the research fromRencana Anggaran kegiatan Fakultas (RKAT) year 2016 so that the research can be well conducted.

\section{References}

[1] Baumber J, Ball BA, Linfor JJ, Meyers SA. 2003. Reactive oxygen species and cryopreservation promote DNA fragmentation in equine spermatozoa. Androl 24: 621-628. 
[2] Pamungkas, H.P.S. 2006.Peran Crude Protein Plasma Seminalis Kambing Terhadap Kualitas Spermatozoa [Skripsi]. Fakultas Kedokteran Hewan. Universitas Airlangga.

[3] Rubinsky, B. 2000. Cryosurgery.Annual Review in Biomedical Engineering.University of California at Berkeley. Berkeley

[4] Madyawati, S.P. 2007. Suplementasi Tirosin Kinase Spermatozoa Sapi Friesian Holstein (FH) Terhadap Kualitas Semen Beku [Disertasi]. Universitas Airlangga. Surabaya.

[5] Aulanni'am. 2004. Prinsip dan Teknik Analisis Biomolekul. Cetakan pertama. Fakultas Pertanian Universitas Brawijaya Press.Hal 16 - 22.

[6] Rantam, F.A.2003. Metode Imunologi. Cetakan pertama, Airlangga University Press, Surabaya.Hal. 79-98.

[7] Hardijanto, S. Susilowati, T. Hernawati, T. Sardjito dan T.W. Suprayogi. 2010. Buku Ajar Inseminasi Buatan. Cetakan 1.Airlangga University Press. Surabaya. 15 - 19.

[8] Hafez, E. S. E. and B. Hafez. 2000. Reproduction in Farm Animals. Philadelphia : Lippicott Williams \& Wilkins. 165-168.

[9] Suyadi, Susilawati, T dan N. Isnaini. 2004. Uji Coba Produksi Semen Beku Kambing Boer. Laporan Penelitian. Fakultas Peternakan. UB. Malang.

[10] Kartasudjana.2001. Teknik Inseminasi Buatan pada Ternak.Departemen Pendidikan Nasional. Jakarta.

[11] Anonimous. 2010. Troubleshooting Sodium Dodecyl Sulfate Polyacrylamide Gel Electrophoresis (SDS-PAGE) [online]. Hycult Biotech. https://www.researchgate.net/file.PostFileLoader.html. Diakses 31 Januari 2017.

[12] Sunarto. 2012. Kadmium (Cd) Heavy Metal Pollutant Bioindicator with Microanatomy Structure Gill Analyses Of Anodonta Woodiana, Lea, Jurnal Ekosains Vol. IV No. 1

[13] Wijaya, S.K.S. dan L. Rohman. 2005. Fraksinasi dan Karakterisasi protein Utama Biji Kedelai. Jember: Fakultas MIPA Universitas Jember.

[14] Sutikno. 2009. Elektroforesis [online]. http://sutikno.blog.uns.ac.id/elektroforesis/. Di akses 31 Januari 2017

[15] Kushartono, B., M. R. Hidayat dan N. Iriani. 2005. Profil Usaha Penggemukan Ternak Domba. Balai Penelitian Ternak.

[16] Lubis, A.M. 2000. Pemberdayaan Bioteknologi Reproduksi Untuk Peningkatan Mutu Genetik Ternak. Wartazoa Vol. 10 No. 1. Balai Penelitian Ternak. Bogor.

[17] Mulyono, S. dan B. Sarwono. 2004. Beternak Domba Profilik. Penebar Swadaya. Jakarta. 
[18] Solihati, N. dan P. Kune.2009.Pengaruh Jenis Pengencer Terhadap Motilitas dan Daya Hidup Spermatozoa Semen Cair Sapi Simmental. 